\title{
MECHANICAL BEHAVIOR OF ENERGETIC MATERIALS DURING HIGH ACCELERATION
}

\author{
Y. Lanzerotti \\ U. S. Army TACOM-ARDEC \\ Picatinny Arsenal, NJ 07806-5000 \\ J. Sharma \\ Naval Surface Warfare Center, Carderock Division \\ West Bethesda, MD 20817
}

\begin{abstract}
The mechanical behavior of explosives subjected to high acceleration has been studied in an ultracentrifuge at $-10^{\circ} \mathrm{C}$ and $25^{\circ} \mathrm{C}$. Melt-cast TNAZ and pressed TNAZ, LX-14, Composition A3 Type II, PAX-2, and PAX-3 have been studied. Failure occurs when the shear or tensile strength of the explosive is exceeded. The fracture acceleration of melt-cast TNAZ is greater than the fracture acceleration of pressed TNAZ at $-10^{\circ} \mathrm{C}$ and $25^{\circ} \mathrm{C}$. The fracture acceleration of $\mathrm{PAX}-3$ is greater than the fracture acceleration of Composition A3 Type II at $-10^{\circ} \mathrm{C}$ and $25^{\circ} \mathrm{C}$. The fracture acceleration of melt-cast TNAZ and pressed TNAZ at $-10^{\circ} \mathrm{C}$ is about $10 \%$ less than that at $25^{\circ} \mathrm{C}$. The fracture acceleration of PAX-3 at $-10^{\circ} \mathrm{C}$ is about 2.6 times that at $25^{\circ} \mathrm{C}$. The fracture acceleration of Composition $\mathrm{A} 3$ Type II at $-10^{\circ} \mathrm{C}$ is about 1.7 times that at $25^{\circ} \mathrm{C}$.
\end{abstract}

\section{INTRODUCTION}

We have introduced several new fields of research to study the mechanical behavior of energetic materials during high acceleration by using an ultracentrifuge. ${ }^{1-11}$ Energetic materials are of significant interest for scientific and practical reasons in the extraction (mining) industry, structure demolition, space propulsion, and ordnance. In these applications the materials can be subjected to high, fluctuating, and/or sustained acceleration. The nature of the fracture 
process of such materials under high acceleration is of particular interest, especially in ordnance and propulsion applications. For example, explosives in projectiles are subjected to setback forces as high as 50,000 $\mathrm{g}$ during the gun launch. These high setback forces can cause fracture and premature ignition of explosives.

Fundamental understanding of the behavior of energetic materials subjected to high acceleration is a key to better practical ordnance designs that solve the problems of abnormal propellant burning and premature ignition of explosives during gun launch. The pressure gradient that is experienced by the explosive during acceleration in the gun and under $g$-loading in the ultracentrifuge is unique and will produce different kinds of behavior and failure than under other material test conditions. The present work is particularly relevant to the future development of insensitive energetic materials to be used in devices with higher acceleration.

Previously, (1-11) we have used an ultracentrifuge to study the fracture behavior of TNT (trinitrotoluene), Composition $\quad$ B $\quad[59 \%$ cyclotrimethylenetrinitramine (RDX), $40 \% \mathrm{TNT}, 1 \% \mathrm{wax}$ ], four types of Octol $[70 \%$ cyclotetramethylenetetranitramine (HMX), 30\% TNT; 75\% HMX, 25\% TNT; $<75 \%$ HMX, 25\% TNT, $<1 \%$ HNS (hexanitrostilbene); and 83\% HMX, 17\% TNT]. In the present work, we studied the fracture behavior at high acceleration in an ultracentrifuge at $-10^{\circ} \mathrm{C}$ and $25^{\circ} \mathrm{C}$ of melt-cast TNAZ (1,3,3-trinitroazetidine), pressed TNAZ, and pressed plastic bonded explosives LX-14 (95\% HMX, 5\% Estane), Composition A3 Type II (91\% RDX, 9\% polyethylene), and PAX-
3 [75\% (85\% HMX, 9\% BDNPF (bisdinitropropyl acetal formal), $6 \%$ CAB (cellulose acetate butyrate)) $/ 25 \%$ aluminum].

\section{TECHNIQUE}

A Beckman ultracentrifuge model L8-80 with swinging-bucket rotor model SW 60 Ti was used to rotate the samples up to $60,000 \mathrm{rpm}(\sim 500,000 \mathrm{~g})$. The distance of the specimen from the axis of rotation ranged from 6 to $12 \mathrm{~cm}$.

The samples were machined into the shape of the frustrum of a cone. The large diameter was typically $11 \mathrm{~mm}$ and the small diameter $9 \mathrm{~mm}$. The angle between the base and the side was $80^{\circ}$. Each sample was fitted into a 5-mm long, 11mm o.d. aluminum cylinder. At one end the i.d. was $11 \mathrm{~mm}$ and at the other end 9 $\mathrm{mm}$. The angle between the inner and outer sides of the sleeve was $10^{\circ}$. The 9$\mathrm{mm}$ diameter top of the sample faced away from the axis of rotation.

For an experiment the acceleration was increased up to a maximum and then held there until the total elapsed time reached 5 min. The sample was then decelerated smoothly. In a series of experiments on a material, the initial maximum acceleration was then increased systematically in each successive 5-min run. The sample fractured when the shear or tensile strength of the material was exceeded, causing particles to break loose from the exposed surface and transfer to the closedend of the tube. A hemispherical fracture surface resulted.

\section{RESULTS}


Melt-cast TNAZ when subjected to high acceleration experiences brittle fracture at grain boundaries. This occurs when the shear or tensile strength of the melt-cast TNAZ is exceeded. The fracture acceleration of pressed TNAZ and the pressed plastic-bonded explosives LX-14, PAX-2A, PAX-3, and Composition A3 Type II also experience brittle fracture when the shear or tensile strength is exceeded.

\section{TNAZ}

The fracture acceleration of melt-cast TNAZ and pressed TNAZ at $25^{\circ} \mathrm{C}$ is given in Table 1. Melt-cast TNAZ was made with $70 \%$ liquid TNAZ and 30\% 40 micron maximum size TNAZ particles. Polycrystalline melt-cast TNAZ has been found to fracture at grain boundaries at $105 \mathrm{~kg}$ at $25^{\circ} \mathrm{C}$. This melt-cast TNAZ was $97.4 \%$ of its theoretical maximum density (TMD) of $1.84 \mathrm{~g} / \mathrm{cc}$. Pressed TNAZ has been found to fracture at $\sim 62$ $\mathrm{kg}$ at $25^{\circ} \mathrm{C}$. This pressed TNAZ was $97.0 \%$ of its TMD.

The fracture acceleration of melt-cast TNAZ and pressed TNAZ at $-10^{\circ} \mathrm{C}$ is given in Table 2. Polycrystalline meltcast TNAZ has been found to fracture at grain boundaries at $\sim 93 \mathrm{~kg}$ at $-10^{\circ} \mathrm{C}$. This melt-cast TNAZ was $97.3 \%$ of its TMD. Pressed TNAZ fractured at $\sim 55 \mathrm{~kg}$ at $-10^{\circ} \mathrm{C}$. This pressed TNAZ was $98.4 \%$ of its TMD.

\section{PRESSED EXPLOSIVES}

PLASTIC-BONDED

The fracture acceleration of melt-cast TNAZ and pressed TNAZ at $25^{\circ} \mathrm{C}$ is compared with the fracture acceleration of LX-14, PAX-2A, PAX-3, and Composition A3 Type II at $25^{\circ} \mathrm{C}$ in Table
1. LX-14 has been found to fracture at $84 \mathrm{~kg}$ at $25^{\circ} \mathrm{C}$. This LX-14 was pressed at $96.9 \%$ of its TMD of $1.849 \mathrm{~g} / \mathrm{cc}$. PAX$2 \mathrm{~A}$ has been found to fracture at $\sim 81 \mathrm{~kg}$ at $25^{\circ} \mathrm{C}$. This PAX-2A was pressed at $99.3 \%$ of its TMD of $1.79 \mathrm{~g} / \mathrm{cc}$. PAX-3 has been found to fracture at $\sim 43 \mathrm{~kg}$ at $25^{\circ} \mathrm{C}$. This PAX-3 was pressed at $97.9 \%$ of its TMD of $1.955 \mathrm{~g} / \mathrm{cc}$. Composition A3 Type II has been found to fracture at $33 \mathrm{~kg}$ at $25^{\circ} \mathrm{C}$. This Composition A3 Type II was pressed at $96.8 \%$ of its TMD of $1.662 \mathrm{~g} / \mathrm{cc}$.

\section{TABLE 1. 1 FRACTURE ACCELERATION OF PRESSED EXPLOSIVES IN AN ULTRACENTRIFUGE AT $25^{\circ} \mathrm{C}$.}

\begin{tabular}{lll}
\hline Explosive & $\begin{array}{l}\text { Fracture } \\
\text { Acceleration } \\
(\mathrm{kg})\end{array}$ & $\begin{array}{l}\text { Density } \\
(\% \mathrm{TMD})\end{array}$ \\
\hline TNAZ(cast) & 105 & 97.4 \\
LX-14 & 84 & 96.9 \\
PAX-2A & 81 & 99.3 \\
TNAZ & 62 & 97.0 \\
PAX-3 & 48 & 97.9 \\
CompA3TII & 33 & 96.8 \\
\hline
\end{tabular}

The fracture acceleration of melt-cast TNAZ and pressed TNAZ at $-10^{\circ} \mathrm{C}$ is compared with the fracture acceleration of LX-14, PAX-2A, PAX-3, and Composition A3 Type II $-10^{\circ} \mathrm{C}$ in Table 2. $\mathrm{LX}-14$ at $-10^{\circ} \mathrm{C}$ did not fracture at the largest acceleration employed in these experiments, $140 \mathrm{~kg}$. This LX-14 was pressed at $95.9 \%$ of its TMD. Similar to the $\mathrm{LX}-14$ result PAX-2A at $-10^{\circ} \mathrm{C}$ did not fracture at the $140 \mathrm{~kg}$ experimental limit. This PAX-2A was pressed at $99.4 \%$ of its TMD. PAX-3 has been found to fracture at $\sim 123 \mathrm{~kg}$ at $-10^{\circ} \mathrm{C}$. This PAX3 was pressed at $97.4 \%$ of its TMD. Composition A3 Type II fractured at $\sim 55$ 
$\mathrm{kg}$ at $-10^{\circ} \mathrm{C}$. This Composition A3 Type II was pressed at $98.1 \%$ of its TMD.

\section{DISCUSSION}

The fracture acceleration of cast TNAZ is greater than that of pressed TNAZ at $10^{\circ} \mathrm{C}$ and $25^{\circ} \mathrm{C}$. Since the fracture acceleration of cast explosives is inversely related to the grain size, ${ }^{1}$ the high fracture acceleration of this melt-cast TNAZ may therefore be due to its very small grain size $(<0.1 \mathrm{~mm})$. The fracture acceleration of melt-cast TNAZ and pressed TNAZ at $-10^{\circ} \mathrm{C}$ was about $10 \%$ less than at $25^{\circ} \mathrm{C}$.

\section{TABLE 2. FRACTURE ACCELERATION OF PRESSED EXPLOSIVES IN AN ULTRACENTRIFUGE AT $-10^{\circ} \mathrm{C}$.}

\begin{tabular}{lll}
\hline Explosive & $\begin{array}{l}\text { Fracture } \\
\text { Acceleration } \\
(\mathrm{kg})\end{array}$ & $\begin{array}{l}\text { Density } \\
(\% \mathrm{TMD})\end{array}$ \\
\hline LX-14 & none & 95.9 \\
PAX-2A & none & 99.4 \\
PAX-3 & 123 & 97.4 \\
TNAZ(cast) & 93 & 97.3 \\
CompA3TII & 55 & 98.1 \\
TNAZ & 55 & 98.4 \\
\hline
\end{tabular}

The fracture acceleration of PAX-3 is greater than that of Composition A3 Type II at $-10^{\circ} \mathrm{C}$ and $25^{\circ} \mathrm{C}$. LX-14 and PAX$2 \mathrm{~A}$ did not fracture at $-10^{\circ} \mathrm{C}$ in these experiments. The fracture acceleration of PAX -3 at $-10^{\circ} \mathrm{C}$ is about 2.6 times that at $25^{\circ} \mathrm{C}$. The fracture acceleration of Composition A3 Type II at $-10^{\circ} \mathrm{C}$ is about 1.7 times that at $25^{\circ} \mathrm{C}$.

Stronger explosives with higher fracture acceleration are less likely to fail. The relationship between sensitivity and strength is not known.

\section{REFERENCES}

1. Lanzerotti, M. Y. D. and Sharma, J. "Brittle Behavior of Explosives During High Acceleration" App. Phys. Letters, Vol. 39, No. 5, 1981, pp. 455-457.

2. Lanzerotti, M. Y. D. and Sharma, J. In "Grain Size and Mechanical Properties Fundamentals and Applications," Otooni, M. A., Armstrong, R. W., Grant, N. J. and Ishizaki, K. (Eds.) Materials Research Society Symposium Proceedings, Pittsburgh, Pennsylvania: Vol. 362, 1995, pp. 131-135.

3. Lanzerotti, M. Y. D., Meisel, L. V., Johnson, M. A., Wolfe, A. and Thomson, D. J. In "Atomic Resolution Microscopy of Surfaces and Interfaces," Smith, D. J. (Ed.) Material Research Society, Pittsburgh, Pennsylvania: Vol. 466, 1997, pp. 179-184.

4. Lanzerotti, M. Y. D. and Sharma, J. In "Shock Compression in Condensed Matter - 1997," Schmidt, S. C., Dandekar, D. P. and Forbes, J. W. (Eds.) American Institute of Physics Conference Proceedings, New York: Vol. 429, 1998, pp. 595-597.

5. Meisel, L. V., Scanlon, R. D., Johnson, M. A. and Lanzerotti, M. Y. D. In "Shock Compression in Condensed Matter 1999," Furnish, M. D., Chhabildas, L. C. and Hixon, R. S. (Eds.) American Institute of Physics Conference Proceedings, Melville, New York: Vol. 505, Part Two, 2000, pp. 727-730. 
6. Sharma, J., Coffey, C. S., Armstrong, R. W., Elban, W. L. and Lanzerotti, M. Y. D. In "Shock Compression in Condensed Matter - 1999," Furnish, M. D., Chhabildas, L. C. and Hixon, R. S. (Eds.) American Institute of Physics Conference Proceedings, Melville, New York: Vol. 505, Part Two, 2000, pp. 719-722.

7. Meisel, L. V., Scanlon, R. D., Johnson, M. A. and Lanzerotti, M. Y. D. In "Multiscale Phenomena in Materials Experiments and Modeling," Robertson, I. M., Lassila, D. H., Devincre, B. and Phillips, R. (Eds.) Materials Research Society Symposium Proceedings, Warrendale, Pennsylvania: Vol. 578, 2000, pp. 363-367.

8. Lanzerotti, M. Y. D. and Sharma, J. In "Processing by Centrifugation," Regel, L. L. and Wilcox, W. R. (Eds.) Kluwer Academic/Plenum Publishers, New York: 2001, pp. 367-369.

9. Sharma, J., Coffey, R. W., Armstrong, W. L., Elban, Lanzerotti, M. Y. D. In "International Workshop on New Models and Predictive Methods for Shock Wave/Dynamic Processes in Energetic Materials and Related Solids," in press.

10. Lanzerotti, M. Y. D. and Sharma, J. In "Shock Compression in Condensed Matter - 2001" Furnish, M. D. (Ed.) American Institute of Physics Conference Proceedings, New York: in press.

11. Lanzerotti, M. Y. D. and Sharma, J. In "Nanopatterning: From UltralargeScale Integration to Biotechnology," Gonsalves, K. E., Dobisz, E. A., Merhari, L., Angelopoulos, M., and Herr, D. J. C., (Eds.) Materials Research Society Symposium Proceedings, Warrendale, Pennsylvania: Vol. 705, in press. 
